\title{
Age and growth studies in silverbellies along Kerala coast
}

\author{
K. J. Abraham, ${ }^{1}$ V. S. R. Murty and ${ }^{2 * K}$ K. K. Joshi \\ Department of Zoology and Aquaculture, St Xavier's College, Vaikom, Kerala, India \\ ${ }^{1 \& 2}$ Central Marine Fisheries Research Institute, P.B. No. 1603, Kochi-682 018, India \\ *E-mail: joshycmfri@ rediffmail.com
}

\begin{abstract}
Age and growth were estimated for five species of silverbellies from samples collected for 24 months from January 1998 along Kerala coast. The estimated values of von Bertalanffy growth parameters are: Eubleekeri splendens $\mathrm{L}_{\infty}=154 \mathrm{~mm}, \mathrm{~K}=0.52 ;$ Leiognathus brevirostris $\mathrm{L}_{\infty}=140 \mathrm{~mm}, \mathrm{~K}=0.86$; Secutor insidiator $\mathrm{L}_{\infty}=130 \mathrm{~mm}, \mathrm{~K}=0.80 ;$ S. ruconius $\mathrm{L}_{\infty}=92 \mathrm{~mm}, \mathrm{~K}=1.19$ and Gazza minuta $\mathrm{L}_{\infty}=160 \mathrm{~mm}$, $\mathrm{K}=1$.7. Length-weight relationship of $E$. splendens $\mathrm{W}=0.000006 \mathrm{~L}^{3.163977}$, S. insidiator $\mathrm{W}=0.0000015$ $\mathrm{L}^{3.463096}$ and S. ruconius was $\mathrm{W}=0.000162 \mathrm{~L}^{2.973626}$. The $\mathrm{K}_{\mathrm{n}}$ value in E. splendens is lowest in the 75-79 mm length group and highest in 100-104 mm length group. In S. insidiator the $\mathrm{K}_{\mathrm{n}}$ value is highest in the 60-64 mm length group. A review of methods available for study of growth has been made and the limitations are discussed. In the ELEFAN method, which has been followed in the present work, the issues confronted are discussed and the ways by which accurate growth parameters could be estimated are discussed.
\end{abstract}

Keywords: Population parameters, silverbellies, length-weight relationship, condition factor

\section{Introduction}

A sound knowledge of growth and age of species contributing to the fishery is essential for understanding the longevity of exploited stocks, age composition of the catch, age at sexual maturity, suitability of different environments for growth, population dynamics and possible identification of stocks on the basis of differences in growth rates. Estimates on age and growth of Indian silverbellies are available (James and Badrudeen, 1975; Murty 1983, 1986a; Jayabalan and Ramamoorthi,1986; Jayabalan,1988; Karthikeyan et al.,1989). In the present study, ELEFAN method using FiSAT package (Gayanilo et al., 1988) has been followed to estimate age and growth of five species of silverbellies off Kerala. The issues confronted in analysis are brought out and the ways by which accurate growth parameters could be estimated, are discussed.

\section{Material and Methods}

The analysis was made from the samples collected from January 1998 to December 1999 from Cochin Fisheries Harbour and Neendakara Fisheries Harbour, which are the major trawl landing centres in Kerala. Since the mechanised trawlers contribute more than $90 \%$ to the landings of silverbellies at both these centres, sampling was done only from these units. Sampling was done at weekly intervals from Cochin and at fortnightly intervals from Neendakara. On each sampling day the units to be sampled were selected following Alagaraja (1984).

\section{Length - weight relationship and relative condition factor}

The length-weight relationship was calculated in Eubleekeria splendens (=Leiognathus splendens, recent nomenclature change, Kimura et al., 2008), Secutor insidiator and S. ruconius following Le Cren (1951) with the help of the equation $\log \mathrm{W}=\log$ a $+b \log \mathrm{L}$, where $\mathrm{W}=$ total weight of the fish in grams and $\mathrm{L}$ is the total length in $\mathrm{mm}$. The relative condition factor $\left(\mathrm{K}_{\mathrm{n}}\right)$ was calculated as the ratio of observed and calculated weights for each length and the averages of different months in all the length 
groups and the averages of different length groups in all the months were considered.

The study is based on length and weight data of 1703 specimens of $E$. splendens $(939$ females, of the length range $72 \mathrm{~mm}-115 \mathrm{~mm}$ and 663 males of the length range $71 \mathrm{~mm}-109 \mathrm{~mm}), 988$ specimens of $S$. insidiator (637 females of the length range $63 \mathrm{~mm}$ $108 \mathrm{~mm}$ and 283 males ranging in length from 80 $\mathrm{mm}$ to $106 \mathrm{~mm}$ ) and 150 specimens of S. ruconius, ranging in length from $38 \mathrm{~mm}$ to $85 \mathrm{~mm}$, collected during the period from January 1998 to December 2000 .

\section{Growth parameters}

The data on five species of silverbellies, $E$. splendens, L. brevirostris, S. insidiator, S. ruconius and Gazza minuta (which account for $90 \%$ of the total landings of silverbellies in the region) were utilised for estimating growth parameters. Length measurements were taken for 28,550 specimens of E. splendens $(45 \mathrm{~mm}-140 \mathrm{~mm}), 5,474$ of $L$. brevirostris ( $64 \mathrm{~mm}-135 \mathrm{~mm}), 13,284$ of $S$. insidiator (51mm- $120 \mathrm{~mm}), 1,873$ of S. ruconius (44 mm- 98 $\mathrm{mm})$ and 3,508 specimens of Gazza minuta $(62 \mathrm{~mm}-$ $180 \mathrm{~mm}$ ). The length data were grouped into $5 \mathrm{~mm}$ class intervals and weighted to the estimated total catch of the species on the date of observation from Cochin and Neendakara centres separately. The estimated length-frequency distribution in all the sampling days were pooled and then weighted to the estimated total catch of the species from each of the centres. Thus the length-frequency distribution in the estimated catch of a species from Cochin and Neendakara landing centres was obtained. The von Bertalanffy growth parameters were estimated for the two years 'data' from each centre separately. The data of the corresponding months from each centre were pooled and subsequently the data from both the centres were pooled. For this purpose the FiSAT package (Gayanilo et al., 1988) was used.

After arriving at best possible estimates of $\mathrm{L}_{\infty}$ and $\mathrm{K}$, the routine in the FiSAT package "output of results" was used to find whether the growth curve was passing through the maximum number of modal lengths in the actual length frequency data. The analysis was carried out using different sets of data until a reasonable, satisfactory value of $\mathrm{L}_{\infty}$ and its compatible K were obtained. Finally the "best" estimates of $\mathrm{L}_{\infty}$ and $\mathrm{K}$ of all the estimates from different sets of data were taken as representing the growth curve of the species.

$\mathrm{L}_{\infty}$ represents the maximum length, a species can attain (Gulland, 1983). Since the von Bertalanffy growth curve represents an "average growth curve", the estimated $\mathrm{L}_{\infty}$ value can be less than the maximum recorded length. Hence, different input values of $\mathrm{L}_{\infty}$ greater and smaller than the maximum recorded lengths were tried. After arriving at best possible estimates of $\mathrm{L}_{\infty}$ and $\mathrm{K}$, the routine in the FiSAT package "output of results" was used to see whether the growth curve was passing through the maximum number of modal lengths in the actual length frequency data.

\section{Results and Discussion}

\section{Length - weight relationship and relative condition factor}

The length-weight relationships were estimated as given below:

E. splendens: $\mathrm{W}=0.0000060 \mathrm{~L}^{3.163977} ; \mathrm{R}^{2}=0.90$

S. insidiator: $\mathrm{W}=0.0000015 \mathrm{~L}^{3.463096} ; \mathrm{R}^{2}=0.80$

S. ruconius : $\mathrm{W}=0.0000162 \mathrm{~L}^{2.973626} ; \mathrm{R}^{2}=0.95$

The average condition factor for each $5 \mathrm{~mm}$ length group was calculated and plotted against the respective length groups for E. splendens (Fig. 1) and $S$. insidiator (Fig. 2). The monthly average

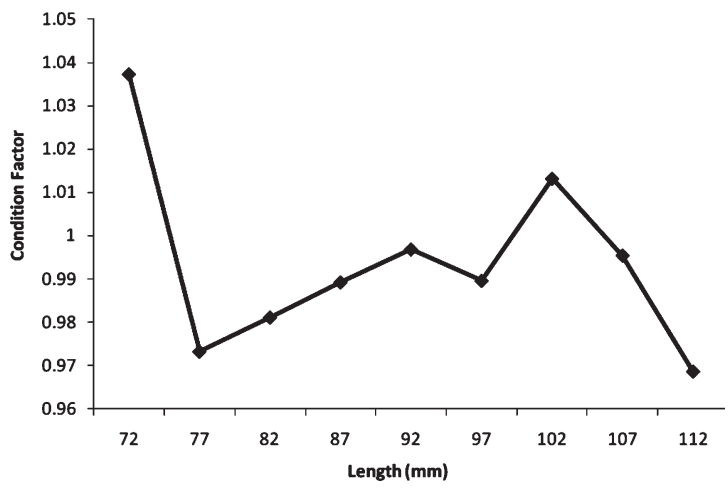

Fig. 1. Condition factor of females in different length ranges in Eubleekeria splendens 
condition factor for different length groups pooled for the different months from October 1998 to December 1999 for both the species are given in Figures 3 and 4 . The $\mathrm{K}_{\mathrm{n}}$ value for E. splendens is the lowest in the 75-79 $\mathrm{mm}$ length group, which corresponds to the length at first maturity for the species (Abraham et al., 2010, MS), and shows the highest value in the 100-104 mm length group. In $S$. insidiator the $\mathrm{K}_{\mathrm{n}}$ value is highest in the $60-64 \mathrm{~mm}$ length group, and thereafter continues at a low level in all the length groups.

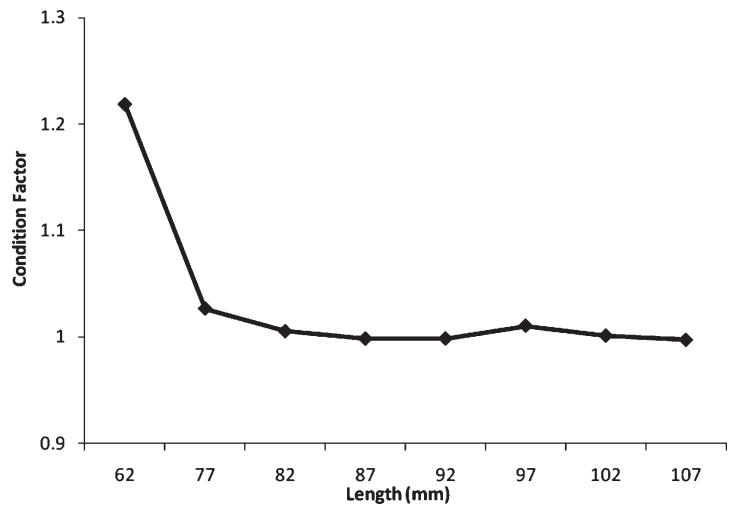

Fig. 2. Condition factor of females in different length ranges in Secutor insidiator

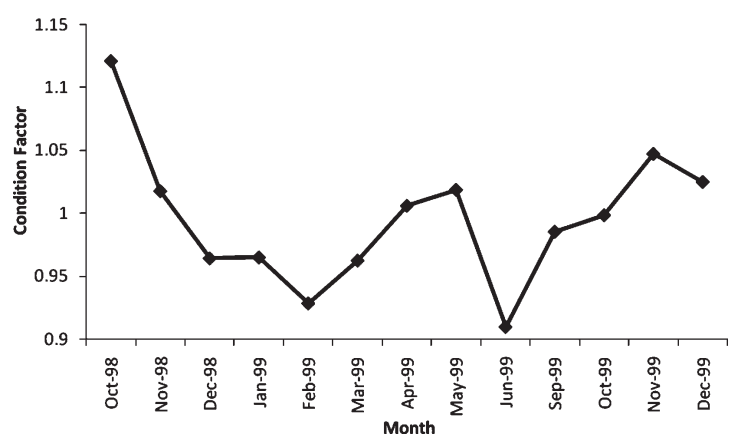

Fig. 3. Condition factor of females in different months in Eubleekeria splendens

In E. splendens, since the condition factor does not show a correlation with the peak spawning period, no valid conclusions could be reached about its variation between months. In $S$. insidiator, the condition factor shows a high value in March 1999, corresponding to a peak occurrence of mature stages (Abraham et al., 2010, MS) and thereafter shows an irregular pattern.

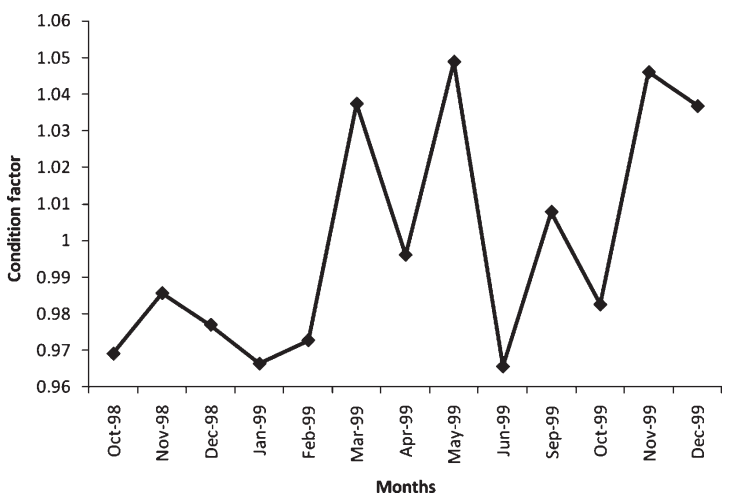

Fig. 4. Condition factor of females in different months in S. insidiator

Studies on length-weight relationship in silverbellies are of Arora (1952) on E. splendens off Rameswaram, Balan (1963) on L. bindus off Calicut, James and Badrudeen (1981) on L. dussumeri from Gulf of Mannar, Murty (1983) on L. bindus off Kakinada, James (1986) on L. jonesi off Palk Bay and Gulf of Mannar, Murty (1986b) on L. bindus along the West Bengal coast, Hameed Batcha and Badrudeen (1992) on L. brevirostris from Palk Bay, and Jayabalan and Krishna Bhat (1997) on $L$. splendens and G. minuta off Parangipettai.

The length-weight relationship in silverbellies determined by earlier authors is given in Table 1. In all the cases the authors analysed the relationship separately for male and female tested the significance of the observed results by analysis of covariance and found that the differences were not statistically significant. Available literature on fishes pertaining to the length-weight relationship of sexes show that they are different only in instances where one sex attains a greater maximum length than the other; in other words there is differential growth rate between sexes in such species (Krishnamoorthi, 1971). In the present study male and female did not show difference in their maximum length. Hence relationship was not calculated separately for the sexes.

\section{Growth Parameters}

The estimated values of $\mathrm{L}_{\infty}$ and $\mathrm{K}$ of the five species are shown in Table 2 and the von Bertalanffy growth equations (VBGF) are given below: 
E. splendens : $\mathrm{Lt}=154\left(1-\mathrm{e}^{-0.52(\mathrm{t}-(-0.19)}\right)($ Fig. 5$)$

L. brevirostris : $\mathrm{Lt}=140\left(1-\mathrm{e}^{-0.86(\mathrm{t}-(-0.0)}\right)$ (Fig.6)

S. insidiator: $\mathrm{Lt}=130\left(1-\mathrm{e}^{-0.80(\mathrm{t}-(-0.001)}\right)($ Fig. 7$)$

S. ruconius: $\mathrm{Lt}=92\left(1-\mathrm{e}^{-1.19(\mathrm{t}-(-0.0)}\right)$ (Fig.8)

G. minuta : $\mathrm{Lt}=160\left(1-\mathrm{e}^{-1.70(\mathrm{t}-(-0.0)}\right)$ (Fig.9)
The length-at-age of the five species, $E$. splendens, L. brevirostris, S. insidiator, S. ruconius and G. minuta derived from VBGF equation is presented in Figures 10 and 11.

As the von Bertalanffy growth parameters are incorporated in the Beverton and Holt yield equation,

Table 1. Length-weight relationship of different species of silverbellies from India

\begin{tabular}{|c|c|c|c|c|c|}
\hline Length-weight relationship & Species & Reference & Locality & a & $\mathrm{b}$ \\
\hline $\log W=-4.8233+3.200 \log L$ & E. splendens & Arora (1952) & Rameswaram & -4.8233 & 3.200 \\
\hline $\log W=-4.7850+2.959 \log L$ & L. dussumieri & $\begin{array}{l}\text { James and } \\
\text { Badrudeen (1981) }\end{array}$ & Gulf of Mannar & -4.7850 & 2.959 \\
\hline $\log W=-4.7771+2.962 \log \mathrm{L}$ & L. bindus & Murty (1983) & Kakinada & -4.7771 & 2.961 \\
\hline $\log W=-5.3822+3.286 \log L$ & L. bindus & Murty (1986) & West Bengal & -5.3822 & 3.286 \\
\hline $\log W=-5.2021+3.216 \log \mathrm{L}$ & L. jonesi & James (1986) & Mandapam & -5.2021 & 3.216 \\
\hline $\log W=-4.4769+2.887 \log \mathrm{L}$ & L. jonesi & $\begin{array}{l}\text { Karthikeyan et al } \\
\text { (1989) }\end{array}$ & Rameshwaram & -4.4769 & 2.887 \\
\hline $\log \mathrm{W}=-5.7371+3.436 \log \mathrm{L}$ & S. insidiator & Murty (1990) & Kakinada & -5.7371 & 3.436 \\
\hline $\log W=-4.8512+3.004 \log L$ & L. brevirostris & $\begin{array}{l}\text { Hameed Batcha and } \\
\text { Badrudeen (1992) }\end{array}$ & Palk Bay & -4.8512 & 3.004 \\
\hline $\log W=-5.2218+3.163 \log L$ & E. splendens & Present study & Kerala & -5.2218 & 3.163 \\
\hline $\log \mathrm{W}=-5.8239+3.463 \log \mathrm{L}$ & S. insidiator & Present study & Kerala & -5.8239 & 3.463 \\
\hline $\log \mathrm{W}=-4.7902+2.973 \log \mathrm{L}$ & S. ruconius & Present study & Kerala & -4.7902 & 2.973 \\
\hline
\end{tabular}

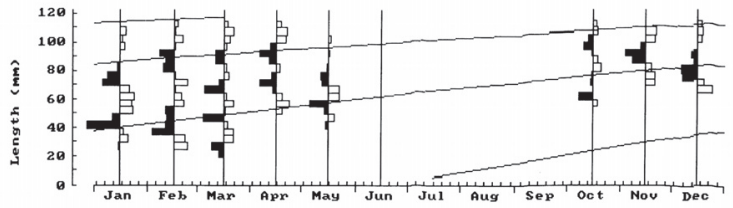

Fig. 5. Restructured growth curve (FiSAT) of Eubleekeria splendens

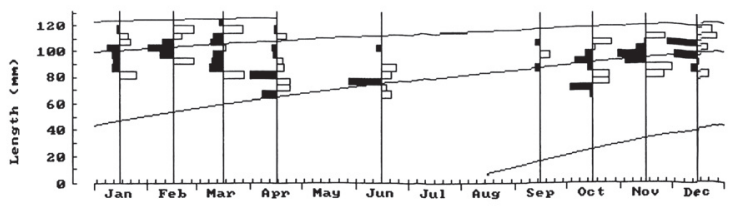

Fig. 6. Restructured growth curve (FiSAT) of Leiognathus brevirostris

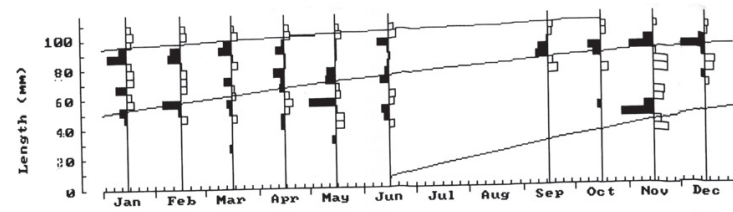

Fig. 7. Restructured growth curve (FiSAT) of Secutor insidiator

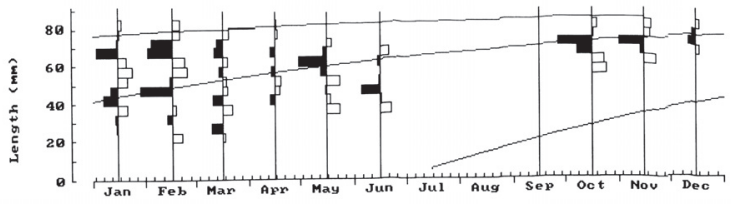

Fig. 8. Restructured growth curve (FiSAT) of S. ruconius

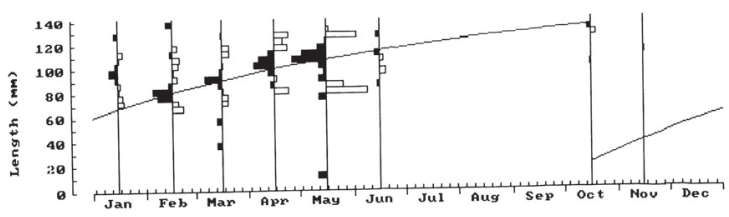

Fig. 9. Restructured growth curve (FiSAT) of Gazza minuta

the validity of the yield curve in any exploited species would depend upon the precision of the estimates of growth parameters. This could be best achieved by ensuring adequate samples of landings such that the samples from the landings could be taken as representing the population with respect to length frequency distribution. In the present study while large representative samples were collected on all the observation days, the possible differences in the 
Table 2. The estimated values of $\mathrm{L}_{\infty}, \mathrm{K}$ and $\phi$ for five species of silverbellies along the Kerala coast

\begin{tabular}{lcccl}
\hline Species & $\begin{array}{c}\mathrm{L}_{\infty} \\
(\mathrm{mm})\end{array}$ & $\begin{array}{c}\mathrm{K} \\
\text { (per year) }\end{array}$ & $\phi^{1}$ & $\mathrm{t}_{0}$ \\
\hline Eubleekeria splendens & 154 & 0.52 & 4.09 & -0.19 \\
Leiognathus brevirostris & 140 & 0.86 & 4.23 & -0.00 \\
Secutor insidiator & 130 & 0.80 & 4.13 & -0.001 \\
Secutor ruconius & 92 & 1.19 & & -0.000 \\
Gazza minuta & 160 & 1.70 & 4.64 & -0.00 \\
\hline
\end{tabular}

length composition between different boats landing on the same day were also taken into account.

Though a number of growth curves are developed, the von Bertalanffy (1934) growth curve is used in fish populations because "it fits most of the observed data of fish growth and can be incorporated readily into stock assessment models" (Gulland, 1983). In the present study, the von Bertalanffy growth parameters were estimated using the ELEFAN method. The ELEFAN method poses certain problems while attempting to extract the "best" growth curves. It has been observed during the analysis that several "best" estimates could be made on the basis of a single data set and it becomes increasingly difficult to really "choose" the most reliable set of growth parameters. On several occasions, high and maximum $\mathrm{R}_{\mathrm{n}}$ values were obtained at $\mathrm{L}_{\infty}$ values much higher than $\mathrm{L}_{\text {max }}$ values known or much lower than the same whereas one would expect $\mathrm{L}_{\infty}$ values to be close to the $\mathrm{L}_{\text {max }}$ values. As the $\mathrm{L}_{\max }$ values known in the literature were taken as seed values initially since the species has the potential to attain lengths close to the $\mathrm{L}_{\max }$, this problem was got over by selecting the growth curves that lead to estimation of $\mathrm{L}_{\infty}$ close to the $\mathrm{L}_{\max }$; and the growth curves that pass through maximum number of positive peaks in the restructured lengthfrequency distribution. The validity of the growth curves chosen was also tested by fitting the growth curve on actual length frequency distribution through the available routine. As this is the first attempt on silverbellies off Kerala coast there was no opportunity to compare similar values from this region. However, considering the frequency and strategy of the sampling, and the care taken in extracting the most reliable values of $\mathrm{L}_{\infty}$ and $\mathrm{K}$, the estimated values may be considered as reliable.

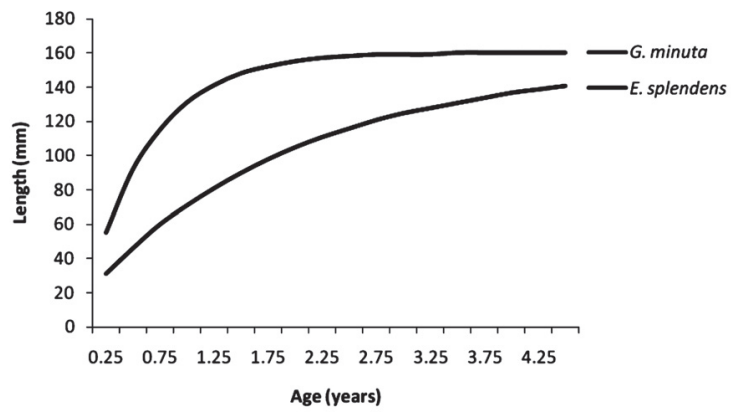

Fig. 10. Growth curves of Gazza minuta and Eubleekeria splendens

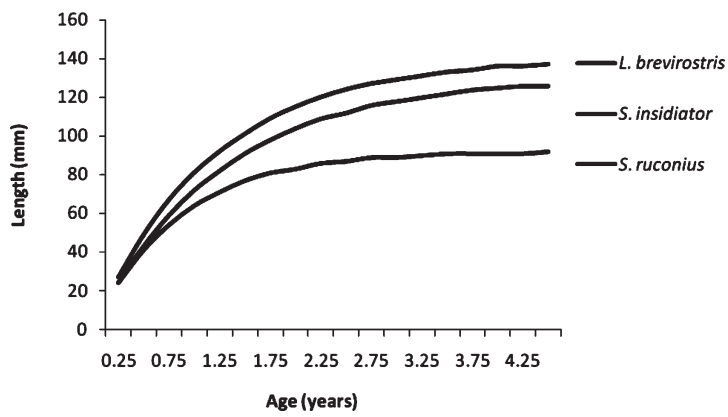

Fig. 11. Growth curves of Leiognathus brevirostris, Secutor insidiator and S. ruconius

\section{Acknowledgments}

The authors are grateful to, Director, C.M.F.R.I., Cochin for the encouragement and facilities provided. The authors also wish to express sincere thanks to Dr. Sathish Sahayak and Shri. N. Rudramurty for their help and support.

\section{References}

Alagaraja, K. 1984. Simple methods for estimation of parameters for assessing exploited fish stocks. Indian J. Fish., 31(2): 177-208.

Arora, H.L. 1952. Contributions to the biology of the silverbelly Leiognathus splendens Cuv. Proc. IndoPacific Fish. Council-3, Technical paper 4: 75-80.

Balan, V. 1963. Biology of the silverbelly, Leiognathus bindus (Val.) of the Calicut coast. Indian. J. Fish., 10: 118-134.

Bertalanffy, L.V. 1934. Untersuchungen uber die Gesetzlichkeiten des Wachstums. 1. Allgemeine Grundlagen der Theorie. Roux'Arch. Entwicklungsmech. Org., 131: 613-653. 
Gayanilo Jr, F.C., M. Soriano and D. Pauly. 1988. A draft guide to the COMPLEAT ELEFAN. ICLARM Software Project 2, 65 pp.

Gulland, J.A. 1983. Fish Stock Assessment - A Manual of Basic Methods. FAO/Wiley Series on Food and Agriculture, Vol. I, 223 pp.

Hameed Batcha and Badrudeen, M. 1992. Lengthrelationship and relative condition of Leiognathus brevirostris (Valenciennes) from the Palk Bay. J. mar. biol. Ass. India, 34(1\&2): 269-270.

James, P.S.B.R. 1986. Biology and fishery of Leiognathus jonesi James from the Palk Bay and Gulf of Mannar. Recent Advances in Marine Biology (Ed. P.S.R.B. James) Today and Tomorrow publishers, New Delhi. 29-101 pp.

James, P.S.B.R. and M. Badrudeen. 1975. Biology and Fishery of Leiognathus brevirostris (Valenciennes) from the Palk Bay and Gulf of Mannar. Indian J. Mar. Sci., 4: 50-59.

James, P.S.B.R. and M. Badrudeen. 1981. Biology and fishery of silverbelly Leiognathus dussumieri (Valenciennes) from Gulf of Mannar. Indian J. Fish., 28(1\&2): 154-182.

Jayabalan, N., 1988. Reproductive biology of the pony fish Gazza minuta (Bloch) from Porto Novo, east coast of India. Indian. J. Mar. Sci., 17(1): 51-54.

Jayabalan, N. and C.H. Krishna Bhat. 1997. Length-weight relationships in the ponyfishes Leiognathus splendens (Cuv.) and Gazza minuta (Bloch) of Parangipettai. Indian J. Fish., 44(3): 291-294.

Jayabalan, N. and K. Ramamoorthi. 1986. Determination of age and growth in the toothed pony fish Gazza minuta (Bloch) from Porto Novo. Mahasagar, 19(30): 217-220.

Karthikeyan, M., N.G.K. Pillai and M. Badrudeen. 1989. Population dynamics of silverbelly Leiognathus jonesi James in the trawling ground off Rameswaram. Indian J. Fish., 36(2): 103-106.

Kimura, S., K. Ikejima and Y. Iwatsuki. 2008. Eubleekeria Fowler 1904, a valid genus of Leiognathidae (Perciformes). Ichthyol. Res. v. 55: 202-203.

Krishnamoorthi, B. 1971. Biology of the Threadfin Bream, Nemipterus japonicus (Bloch). Indian J. Fish., 8: 121.

Le Cren, E.D. 1951. The length-weight relationship and seasonal cycle in gonad weight and condition in the perch (Perca fluviatilis). J. Anim. Ecol., 20: 201219.

Murty, V.S. 1983. Observation on some aspects of the biology of silverbelly Leiognathus bindus (Valenciennes) from Kakinada. Indian J. Fish., 30(1): 61-68.

Murty, V.S. 1986a. Studies on the growth and population dynamics of silverbelly Lieognathus bindus (Valenciennes) in the trawling grounds off Kakinada. Indian J. Fish. 34: 265-276.

Murty, V.S. 1986b. Population characteristics of the silverbelly Leiognathus bindus (Valenciennes) along the West Bengal coast. J. mar. biol. Ass. India, 28: 4147.

Pauly, D. and D.N. David. 1981. ELEFAN I, a BASIC program for the objective extraction of growth parameters from length-frequency data. Meeresforschung, 28(4): 205-211.

Received : 18/11/2010

Accepted : 07/03/2011

Published : 15/12/2011 